\title{
Ecological problems of animal industry of modern agglomeration
}

\author{
O. Tertychna, Candidate of Biological Sciences \\ V. Pinchuk, Candidate of Agricultural Sciences \\ R. Stepanov \\ Institute of Agroecology and Nature Management of NAAS \\ V. Boroday, \\ Doctor of Agricultural Sciences \\ National University of Bioresources and Natural Resources of Ukraine Environmental Problems of \\ Industrial Livestock in Modern Agglomeration Objective
}

The purpose. Trends are analyzed in development of animal husbandry (on an instance of Kiev region) for the last 20 years and preventive ecological evaluation of influence of this branch on state of environment in a context of stable development of the region. Methods. Analytical-synthetic, generalizations, calculations, mathematical, statistical. Results. It is shown that in comparison with 1995 the number of cattle and pigs in 2015 dropped in 7,3 and 1,4 times accordingly, livestock of auk increased in 2,4 times. The amount of solid animal wastes (1812,8 thousand t/year), volumes of ammonia (20674,8 thousand tons) are calculated. Contamination by wastage and sewage is surveyed as the important ecological problem which demands ecologically safe and economically expedient solution. The volume of the gained biogas in cattle-breeding factories makes 25 million m3. Conclusions. Intensive animal husbandry results into pressure on environment through contamination by collateral products of cattlebreeding parentage.

Key words: animal husbandry, environment, ecological problems, collateral products, bioenergetics.

Introduction. The development of the livestock industry to provide the population with full protein products is currently an important strategic goal of national food security. Livestock intensification and transfer it on an industrial basis creates a wide range technocratic environmental issues. As a result of livestock production there are emissions to atmosphere, hydrosphere and soil from livestock units. In Ukraine, according to the calculations of national scientists, the poultry production is responsible for $72 \%$ of atmospheric pollutants (greenhouse gases), respectively by the pig $-19 \%$, other sectors $-9 \%$ [1]. Waste and by-products removal, recycling and use isone of the most difficult problems of industrial farming, which is part of the waste management strategy. Finding the ways of by-products of production and wastewater recycling in the livestock industry is relevant and important not only for Kyivregion but for the whole country. It's solution is of great ecological and economic importance [2]. According to Hermann V. V. regional sustainable development of natural-resource potential, where is the livestock production is concentrated, is not possible without the combination of activities that require the use of modern technology in all stages of agricultural production, by meeting environmental requirements and international legislation [3].

Kiev region, which occupies $4.7 \%$ of the total area of Ukraine with 1.73 million population, is an important region for economic and social development of the country. The purpose of this study was to analyze the trends of livestock development (on the example of Kyiv region) over the past 20 years and preventive environmental assessment of the impact of this industry on the state of environment in the context of sustainable development of the region .generalization methods of the processed statistical data of the livestock of agricultural animals and production of livestock products of the Main Department of statistics in Kyiv region [4]. To calculate the ammonia emission from by-products of animal husbandry used the estimated coefficients according to [5].

The results of the research. According the dynamics of all categories the livestock on farms in Kyiv region for the past 20 years. There was the same trend generally in Ukraine: reduction in numbers of cattle (from 988,8 to 138,4 thousand heads),small cattle (from 64.6 to 31.5) and pigs (from 715,2 to 487,5 thousand heads). And the same time, the rapid growth of poultry (from 11.7 to 28.1 million head). In addition, to chickens there is an increaseof otherpoultryspecies, i.e. ducks, turkeys, ostriches, quails (200 thousand animals), currently, in Kiev region $[4,6]$. 
The major part of the livestock industry of Kyiv region is concentrated in agricultural enterprises except small cattle. The predominated number of livestock is in the private sector (table. 1). The livestock is developingon the intensive basis, that when a large number of animals is concentrated in a small area.

Table 1. Livestock of agricultural animals by categories of enterprises of Kyiv region (December 1, 2015) thousand heads.

\begin{tabular}{|c|c|c|c|c|c|c|}
\hline \multirow[b]{3}{*}{ Typeofanimal } & \multirow{2}{*}{\multicolumn{2}{|c|}{$\begin{array}{l}\text { Allcategoriesofen } \\
\text { te rprises }\end{array}$}} & \multicolumn{4}{|c|}{ Including } \\
\hline & & & \multicolumn{2}{|c|}{$\begin{array}{l}\text { Agricultural } \\
\text { Enterprises }\end{array}$} & \multicolumn{2}{|c|}{ Private sector } \\
\hline & $\begin{array}{l}\text { Thousa } \\
\text { nd heads }\end{array}$ & $\begin{array}{c}\% \text { up to } \\
1 \\
\text { Dec. } 201 \\
4\end{array}$ & $\begin{array}{l}\text { Thousan d } \\
\text { heads }\end{array}$ & $\begin{array}{c}\% \text { up to } 1 \\
\text { Dec.2014 }\end{array}$ & $\begin{array}{l}\text { Thous } \\
\text { and } \\
\text { heads }\end{array}$ & $\begin{array}{c}\% \text { up to } \\
1 \\
\text { Dec. } 201 \\
4\end{array}$ \\
\hline Cattle & 138,4 & 98,6 & 88,4 & 100,0 & 50,0 & 96,2 \\
\hline Including cows & 69,9 & 92,7 & 34,6 & 93,5 & 35,3 & 91,9 \\
\hline Pigs & 487,5 & 89,6 & 349,1 & 90,4 & 138,4 & 87,4 \\
\hline Sheep and goats & 31,5 & 108,2 & 5,7 & 111,8 & 25,8 & 107,5 \\
\hline Poultry & 28125,5 & 102,2 & 21910,1 & 99,6 & 6215,4 & 112,5 \\
\hline
\end{tabular}

The number of cattle is 145 thousand heads $(+9.2$ thousand heads to the beginning of the year),according to the Department of agricultural development of Kyiv regional state administration, for October 1, 2015.the region's farms In the agricultural enterprises of the region the number of cattle amounted to 89,9 thousand heads ( +2.2 thousand goal. to the beginning of the year). Increase the number in Kagarlytsky $(+414$ goal. to M. H.), Township (+ 405 goal. to M. H.) areas. The number of cows in all categories of farms amounted to 72.5 thousand heads, including 35,5 thousand goal. in agricultural enterprises.

According to the Department of agricultural development of Kyiv regional state administration as of October 1, 2015 the region's farms the number of cattle amounted 145,0 thousand heads $(+9.2$ thousand headsat the beginning of the year). In the agricultural enterprises of the region the number of cattle is 89,9 thousand heads ( +2.2 thousand headsat the beginning of the year). There is an increase of the number in following areas: Kagarlitski ( +414 heads till previous year), Yagotinski $(+405$ heads till previous year). The number of cows in all farm categories estimated to 72.5 thousand heads, including 35,5 thousand heads in agricultural enterprises.

As at 01.10 .2015 the number of pigs estimated to 501,3 thousand heads, of which 357,0 thousand heads in agricultural enterprises. The number of pigs in all categories of Kyiv region takes the 2 nd place in Ukraine.

The increase of the cows number in following areas:Yagotinski (+ 148 heads till previous year), Tetivski (+ 98 heads till previous year),Vyshgorod (+63heads till previous year),Mironivski (+ 48heads till previous year), areas. As at 01.10 .2015 the number of pigs amounted to 501,3 thousand heads, of which 357,0 thousand heads in agricultural enterprises. Number of pigs in all categories of Kyiv region takes the 2nd place in Ukraine.

There is an increase in the number of pigs in Barishivski area (+ 15778 heads till previous year),Kagarlickiy area (+ 5364 heads till previous year)

The number of birds in the region was estimated to 27.0 million heads, including in agricultural enterprises of 20.0 million heads. Kyiv region takes the $2^{\text {nd }}$ place, among all Ukrainian regions by the number of poultry [7].

Changes in livestock of different species of farm animals during 1995-2015, respectively influenced on the structure of production of major livestock products of the Kiev region ( Fig. 1). Compared with 1995 there has been an increase in meat production in slaughter weight in 1.55 times, the production of eggs in 2, 55 times and the same time a decrease in milk production in 2, 46 times.

For the period from January to October, 2015 the sold volume of livestock and poultry for the slaughter in live weight in all categories of farms of Kyiv region was 220.3 thousand tons, the third place in Ukraine. 


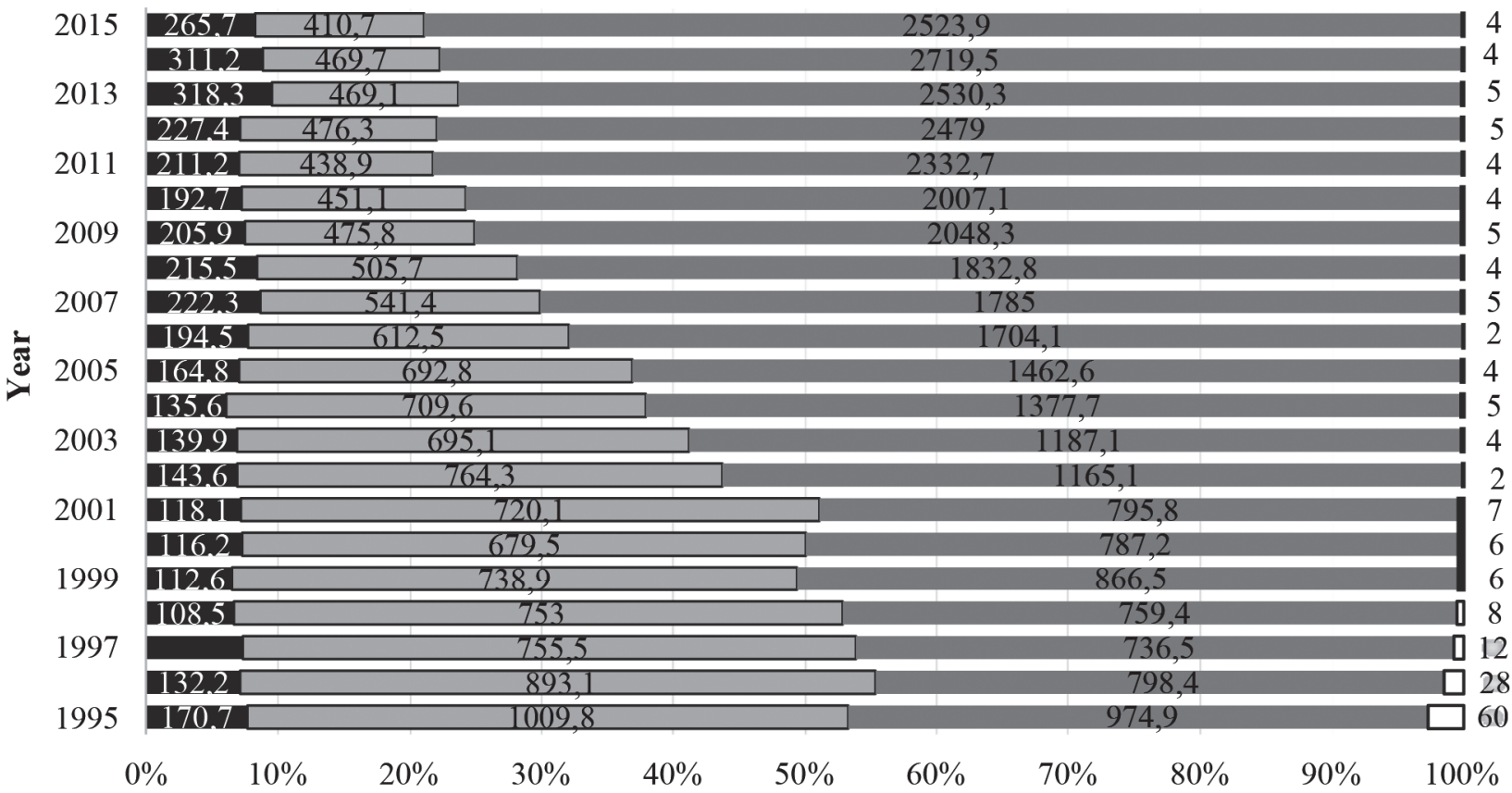

Meat (slaughter weight), thsd,tones $\square$ milk, thsd, tones $\quad$ egg, million $\quad \square$ wool, tone

Fig. 1.The production of main products in Kyiv region over the last 20 years (1995-2015.)

The anthropogenic loading from livestock production calculation (table.2). Modern livestock industry of Kyiv region develops on an intensive basis with a

large number of animals concentrated in a small area. Livestock intensification and transfer it on an industrial basis creates a wide range of environmental problems. The anthropogenic loading from livestock production calculations (table.2).

Table2. Environmental footprint from livestock production in the Kiev region and in Ukraine(on 15.01.2016)

\begin{tabular}{|l|c|c|c|c|c|}
\hline Indicators & $\begin{array}{l}\text { Area, thsd. } \\
\mathbf{k m}^{2}\end{array}$ & Population, $\mathbf{m l n}$. & $\begin{array}{l}\text { Heads of poltry, } \\
\text { mln. }\end{array}$ & $\begin{array}{l}\text { Heads of pigs, } \\
\text { thsd }\end{array}$ & $\begin{array}{l}\text { Cows } \\
\text { heads,thsd. }\end{array}$ \\
\hline Ukraine & 603,6 & 42,8 & 209,9 & 7093 & 3776,5 \\
\hline Kyiv, region & 28,1 & 1,7 & 28,1 & 487,8 & 138,5 \\
\hline$\%$ from total & $4,7 \%$ & $42,9 \%$ & $13,4 \%$ & $6,8 \%$ & $3,6 \%$ \\
\hline
\end{tabular}

The formation of significant amounts of waste is a characteristic feature of animal husbandry. According to the dynamics of a livestock of agricultural animals in recent years in the Kyiv region, there has been an increase in amount of waste in the livestock industry. According to our estimates in 2015, the amount of solid waste from cattle amounted 252,6 thsd tones per year, pig adds 533,8 thsd tones per year of waste, poultryis 1026,5 thsd per year.

The general estimated amount of solid waste from livestock production in Kiev region is 1812, 9 thsd tones per year. This doesn't include accumulated waste from year to year. With current rate of livestock developmentsector, the poultry industry can become a major source of environmental pollution waste production (manure, litter, dead birds, carcases and products of their decomposition) (table. 3). The anthropogenic load on the territory of Kyiv region from a solid wastes from main types of agricultural animals in general is $64.7 \mathrm{t} / \mathrm{km}^{2}$ land area per /year, or $170 \%$ of the average for Ukraine.

One of the ways to make the livestock sector more eco-safe is the improvement of technologies for utilization of by-products and animal waste in the direction of full use of the physical mass and nutrients of manure that reduces the pollution of water sources, and reduce the release into the environment of ammonia and greenhouse gases. 
Table3. The estimated amount of solid waste, emissions of ammonia from the waste of the livestock sector of the Kyiv region (2015)

\begin{tabular}{|l|c|c|c|c|}
\hline Animal type & $\begin{array}{c}\text { Solid waste thsd } \\
\text { tones per year }\end{array}$ & $\begin{array}{c}\text { Wastes, \% } \\
\text { 'V' } 2014 \mathrm{p} .\end{array}$ & $\begin{array}{c}\text { Wastes per area } \\
\text { unit, tones/km²/year }\end{array}$ & $\begin{array}{c}\text { Ammoniaemission, } \\
\text { tones/year }\end{array}$ \\
\hline Cows & 252,6 & 99,2 & 9,02 & 3972,1 \\
\hline Pigs & 533,8 & 93,4 & 19,1 & 7702,5 \\
\hline Poultry & 1026,5 & 101,9 & 36,6 & 9000,2 \\
\hline
\end{tabular}

The following steps are suggested to overcome the negative environmental consequences in the processing of manure and dung: the organization of industrial processing of litter and manure to produce organic fertilizers; the use of bioenergy plants.

The adoption of each of these solutions have the following advantages, firstly, for industrial processing: saving of nitrogen, phosphorus, potassium and other elements that primary fresh raw material holds; fermentation occurs under appropriate supervision, therefore, timely amendments to the process; eliminating the emission of odors during storage and use;get environmentally friendly organic fertilizer in a concentrated form. Secondly, the organic fertilizers are in a great demand, organic fertilizers give the opportunity to refuse the use (or reduced use) the mineral ones. The production of ecologically clean products; increase crop yields; improve the biological and physico-chemical properties of soils, as a consequence.

The production of eco-safe organic-mineral fertilizer based on chicken manure, waste water, is highlypromising. That helps not only to increase the crop productivity but also the ecological status of the soil itself [8]. Considering, the current realities of biogas technologies implementation is considered as one of the possible ways to achieve energy independence of Ukraine. In the future, biogas plant will allow to receive2.6-18 billion $\mathrm{m}^{3}$ natural gas per year, in Ukraine.

\section{Table 4 shows the parameters of existing biogas plants working on livestock}

enterprises in Kiev region[9]. According to our calculations these enterprises produce about 3.5 million $\mathrm{m}^{3}$ per yearand for the entire period there was received 25 million $\mathrm{m}^{3}$ of natural gas. In addition to the energy production cycle, the environmental problems to obtain organic compost is destroyed unpleasant odour.

Beside from the energy supply of the production cycle, dealing with ecological issues: there is a production of organic compost with destruction of unpleasant odour. The pathogens are completely destroyed, as evidenced by the decrease in two-three times in fermented biomass-titres. But it should be noted that bioenergy technology and plants on the territory of Kyiv region and generally in Ukraine are used insufficiently because of considerable price and lack of domestic production.

Their purchase from abroad requires substantial investment. This leads to the fact that the risks for final production cycles are known, but not eliminated. However, the government is interested in solving the problems associated with the soil restoration, purity of water supplies, organic foods and many other citizens healthrelated issues and a clean environment, so the use of the latest facilities and modern technologies for bioenergy and organic fertilizers need to be addressed at the government level.

Table 4. The use of biogas plants by the livestock sector in the Kiev region.

\begin{tabular}{|c|c|c|c|}
\hline № & Enterprise & $\begin{array}{l}\text { Agricultural } \\
\text { Enterprise «Elita» }\end{array}$ & $\begin{array}{l}\text { Catle Farm «Ukrainian } \\
\text { Milk company» }\end{array}$ \\
\hline 1 & Year of establishment & 2009 & 2009 \\
\hline 2 & Heads & 1000 & 6000 \\
\hline 3 & Raw materials & $\begin{array}{l}\text { Manure } \\
\text { catle }+10 \% \text { pigs })\end{array}$ & Manure of catle \\
\hline 4 & Mass of raw materials, tones/day & 60 & 400 \\
\hline 5 & Biogaspreoduction, v, $\mathrm{m}^{3} /$ day & 1500 & 8200 \\
\hline 6 & Power, MVtel & 0,25 & 0,625 \\
\hline 7 & Tehnology & «LIPP»Germany & «Zorg»Ukraine+Germany \\
\hline
\end{tabular}


There are following examples of solutions may be considered: reducing taxes when bioenergy production implemented; temporary exemption from tax on profits payments of producers of bioenergy equipment; implementation of "green tariff", the provision of soft loans for the purchase of equipment for biogas production.

The Kyiv region is located in the middle basin of the Dnieper. The Kiev region's water resources have a great potential. This dense river network include in itself 1522 rivers with a total length of $8745 \mathrm{~km}$, where the most Important waterway is Dnieper river. Dnieperriverflows in the boundary region of $246 \mathrm{~km}$ of Its tributaries, the Pripyat, Teterev, Irpen, Ros, Desna and Trubizh. Besides this, there are 58 reservoirs, 2389 ponds, and approximately 750 small lakes [10]. That's why saving hydro basin is a global environmental problem of the region.

The sanitary and environmental state of waste water from livestock enterprises is under particular concern. Their composition is a special danger for the environment: mineral and organic xenobiotics, disinfectants, insecticides, medicines.

The waste water after processing, cleaning of premises, equipment requires the bio security monitoring, storage and waste disposal. Our research on the state of wastewater poultry farms in the Central region of Ukraine testify that itssanitary condition after technological processing does not eliminate the negative processes that affect the livelihoods of individual aquatic organisms, and the overall functionality of the whole aquatic ecosystem, are exposed to this wastewater.

Most of these processes show the same results of sanitary, environmental studies of water surface of rivers and reservoirs in points of wastewater from factories [ 1,10].

So, Kyiv region has a high level of anthropogenic load on the environment from livestock production. Especially, "environmentally unfriendly" decision on the handling of origin of animal waste: air pollution from nitrogen compounds and greenhouse gases, water, by nitrates and toxic pollutants, soil, by heavy metals, the deterioration of the epizootic status and other negative consequences.

A solution to the waste problem is seen in the development of innovative technologies storage and application of manure, implementation under international environmental regulations of agricultural production, whichwill provide additional competitive advantages, particularly in reducing fertilizers costs.

The ecological security problems are interlinked with the prospects of ecologization of production. The main objectives of ecologisation in livestock production is to reduce the pollution sources impact on the environment, improve livestock enterprisesecological and economic performance, environmental management system modernization, the transition to waste-free technologies, and the careful use of non-renewable resources, to ensure the production of eco-safe products are the main objectives of the ecologisation of production of poultry products.

\section{Conclusions}

Thus, according to the analytical laboratoryresearch of agrobioresource monitoring of Institute of Agroecology and Natural Resources Management NAAS of Ukraine, Kyiv region has a considerable level of anthropogenic load on natural from pollution by industrial waste of animal origin. This, in turn, leads to air pollution with nitrogen compounds and greenhouse gases. The basis of environmental problems the decision of animal husbandry is carrying out a systematic monitoring in areas of intensive livestock production, identification of anthropogenic pollution indicators and implementation of environmental legislation. The further economic development of agriculture in the Kiev region requires the use of the livestock production with the use of modern green technologies that will enhance the revival of natural-resource potential of the region and not lead to the destruction of natural ecosystems.

\section{Bibliography}

1. Zhukorskyi O. Emissions of air pollutants from area livestock industry in Ukraine/O. Zhukorskyi, L. Moklyachuk, O. Nykiforuk//Agricultural science and practice. — 2014. — № 2. - P. 39 - 44.

2. Herman V.V. Ekolohichna bezpeka pry vyrobnytstvi tvarynnyts'koyi produktsiyi/ V.V. Herman//Ahroekolohichnyy zhurnal. - 2009. - \# 2. - S. 5 - 8.

3. Ekolohichna bezpeka ahropromyslovoho vyrobnytstva: monohrafiya; za nauk. red. O.I. Furdychka, A.L. Boyka. - K.: DIA, 2013. - $416 \mathrm{~s}$. 
4. Statystychnyy shchorichnyk Kyyivs'koyi oblasti//Holovne upravlinnya statystyky u Kyyivs'kiy oblasti. 2016. $-480 \mathrm{~s}$.

5. Kakareka S.V. Model'naya stratehyya snyzhenyya vыbrosov ammyaka (na prymere respublyky Belarusy)/S.V. Kakareka, A.V. Mal'chykhyna, A.S. Pylypchuk//Working Group of Strategies and Review, 49th Session 12 - 16 September. - Geneva, 2011. - 17 c.

6. Zherebov M.Ye. Pro stan roboty haluzi ptakhivnytstva Kyyivshchyny za 2014 rik/ M.Ye. Zherebov/Suchasne ptakhivnytstvo. - 2015. - \# 1 - 2 (146-147). - S. 10 - 13.7. Shih J.C.H. From biogas energy, biotechnology to new agriculture//World's Poultry Science J. -2012 . — V. 68. — № 3. P. $409-417$.

8. Dehodyuk Ye.H. Piddaty otrutu konversiyi//The Ukranian farmer. — 2016. — \# 4. — S. 16 - 18.

9. Heletukha H.H. Perspektyvy vyrobnytstva ta vykorystannya biometanu v Ukrayini. — Analitychna zapyska Bioenerhetychnoyi Assotsiatsiyi Ukrayiny/H.H. Heletukha, P.P. Kucheruk, Yu.B. Matvyeyev. — 2014. — \# 11. $-42 \mathrm{~s}$

10. Vodnyy fond Ukrayiny: dovidkovyy posibnyk; za red. V.M. Khoryeva, K.A. Aliyeva. - K.: Nika-tsentr, 2001. - $392 \mathrm{~s}$

11. Ecological problems pollution waste water of production poultry products/O. Tertichnaya, $\mathrm{V}$. Boroday, O. Mineralov, R. Stepanov//Agroecological j. — 2015. — № 4. - P. $48-53$. 